\title{
Władysław Czapliński*
}

\section{PALESTINE V. US BEFORE THE INTERNATIONAL COURT OF JUSTICE?}

\begin{abstract}
In December 2017, the administration of President D. Trump decided to move the US embassy in Israel from Tel Aviv to Jerusalem. On 28.09.2018, Palestine initiated proceedings against the US in connection with the said transfer. According to the ICJ Statute, only the parties of concern can take part in the case before the Court. However, it does open the way for non-member countries that had presented a declaration of submission to the Court's jurisdiction, to observe. If there are any doubts as to the validity or effects of the declarations, they are decided by the ICJ. In the present case, doubts are connected, in particular, with the status of Palestine as a State, with the status of Jerusalem and with the participation in the proceedings of all interested parties. It is unclear whether Palestine meets the criteria of statehood under international law, and the nation is far from being universally recognized. Nor may the GA Resolution 67/19 be viewed as sufficient collective recognition. Furthermore, we do have reasonable doubt as to whether this is sufficient collective recognition to be essentially constitutive of Palestine's statehood. This situation is not changed by the acceptance by Palestine of the jurisdiction of the ICC nor accession to UNESCO and to a number of international treaties.
\end{abstract}

On the other hand, the jurisdiction of Israel with respect to East Jerusalem is also disputed. Certain international bodies, including

* Professor, Institute of Law Studies of the Polish Academy of Sciences, Warsaw 
the UNSC, have expressed doubts equally regarding the incorporation of Jerusalem into Israel or that Palestine has claim to the city. The mere submission of a claim by Palestine does not prejudge the existence of a legal title to Jerusalem. The legitimation of Palestine to bring to international court a claim is thus disputable under the law on state responsibility.

It is probable that the ICJ would avoid rendering a decision on merits of the dispute, doing so by referring to the principle of Monetary Gold that was formulated by the ICJ in a judgment on 15.06.1954 in a dispute between Italy, on the one hand, and Great Britain, France and the US, on the other. The subject of the dispute was the fate of gold owned by the National Bank of Albania, plundered by Germany in Rome in 1943. In accordance with an arrangement concluded at the Paris Conference on German reparations (14.01.1946), all gold found in Germany that was known to have been plundered was to be returned in proportional shares to the States concerned. In the case of Albania, however, difficulties appeared in connection with two issues: claims by some States (in particular Italy) resulting from nationalisation of the National Bank of Albania, and compensation in favour of the UK due to the ICJ judgement in the Corfu Channel. It was disputable whether the gold belonging formerly to Albania could be redistributed among the unsatisfied claimants without the consent of the Albanian State. The Tribunal avoided the problem and decided that it lacked jurisdiction. It refused to render judgment in a situation in which Albania did not participate in the trial; on the other hand, the ICJ has indicated on what terms Albania could join the proceedings. Albania did not meet the conditions, and the Court decided that it was unable to continue the proceeding.

Keywords: Vienna Convention on Diplomatic Relations, diplomatic mission, State of Palestine, recognition

\section{Introduction}

In December 2017, the administration of President D. Trump decided to move the US embassy in Israel from Tel Aviv to Jerusalem. The basis for such action was the law passed by Congress in 1995. The new embassy inaugurated the activity on 24.5.2018. From the very beginning, the decision of the American administration aroused opposition from the international community. Nevertheless, there was no sudden reaction (especially from 
the Arab world); however, a few countries have followed the US: Honduras, Guatemala, Romania, Australia and Brazil.

On 28.9.2018, the State of Palestine (referring here to the terminology used in the ICJ press release) initiated proceedings against the US in connection with the transfer of the American embassy to Jerusalem. ${ }^{1}$

The jurisdiction of the ICJ ratione personae is set out in Article 34 of the Statute of the Court. It provides that only the parties can take part in the case before the Court. A State in the Court should be, in principle, a member of the UN or a party to the ICJ Statute. However, the Statute of the Court, in Article 35(2), opens the way for non-member countries, with the conditions of such participation in the proceedings to be determined by the UNSC, which should take into account existing international agreements (providing for the jurisdiction of the Tribunal). Such an instrument is Resolution 9 (1946) of 15.10.1946, which makes access to the Court conditional upon submitting a declaration of submission to the Court's jurisdiction, including a clause requiring that the Court's decisions be made in good faith and that the ruling is enforced. This declaration may cover all disputes arising in the future or for a specific, existing dispute. In the past, two countries have made specific declarations (Albania 1947, Italy 1953), and eight states - general declarations (including i.a. Germany five times, Finland twice, Italy, and Japan). The basis of jurisdiction is, in this case, the declaration made under Article 35(2) of the ICJ Statute in conjunction with UNSC Resolution 9 (1946), in conjunction with the declaration made at the Court on 4.7.1918 regarding jurisdiction of the ICJ that may arise or that has already arisen in connection with diplomatic relations. Palestine acceded to the Convention on 22.11.2018, and the US on 13.11.1972. ${ }^{2}$

1 Relocation of the United States Embassy to Jerusalem (Palestine v. United States of America), ICJ, Application Instituting Proceedings, https://www.icj-cij.org/files/ case-related/176/176-20180928-APP-01-00-EN.pdf.

2 In the Legality of Use of Force case [1999] ICJ proprio motu interpreted Article 35(2) of the Statute and decided that the declaration could cover exclusively treaties containing jurisdiction clauses and concluded before the entry into force of the ICJ Statute. This should exclude the admissibility and legality of the Palestinian declaration.

As to the opinions of international legal authors on the scope of jurisdiction of international judicial bodies with respect to Palestine, see M. Whitman, Palestine's Statehood and Ability to Litigate in the ICJ, "California Western International Law Journal" 2013, vol. 44, no. 1, p. 73; P. Palchetti, La participation de la Palestine à la procédure devant la Cour internationale de justice, [in:] T. Garcia (ed.), 'La Palestine: d'un Etat non membre de l'Organisation des Nations Unies à un Etat souverain?', Éditions A. Pédone, Paris 2016, p. 79; V. Azarova, The Trickle-down Effect of Normative Power: the Role of International Courts 
This declaration is, in practice, the equivalent of a judicial compromise, i.e. a bilateral agreement between the States concerned, which decide to submit their dispute to the Tribunal. According to paragraph 5 of cited Resolution 9 (1946), as well as Article 41 of the Rules of Procedure of the ICJ, if there are any doubts as to the validity or effects of the declarations, they are decided by the ICJ. In our case, doubts will be connected, in particular, with the status of Palestine as a State, with the status of Jerusalem and with participation in the proceedings of all interested parties.

\section{Palestinian Statehood?}

Although not very probable, the possible confirmation of Palestinian statehood by the ICJ could have important legal consequences. If Palestine is a State, then it is entitled to all of the rights of States under international law, including immunities of the State and its officials, protection from the use of force by other States, the right of self-defence and collective self-defence in the event of an armed attack against it, plenary jurisdiction over its territory, the prohibition of intervention in matters essentially within its domestic jurisdiction, the possibility of membership in other intergovernmental organisations and specialised agencies and full treatymaking capacity. Statehood could also provide access to international courts and other dispute settlement mechanisms. In particular, if Palestine is a State, it can enable the ICC to exercise jurisdiction over crimes committed on its territory, even if those crimes have been committed by nationals of States that are not States Parties to the Rome Statute.

The present notion of the State of Palestine is connected with a certain political structure in statu nascendi, proclaimed by the Palestinian National Council at the meeting in Alger on 15.11.1988. There are some indications that a number of international subjects (States and international organisations, including the UN and the League of Arab States) recognised Palestine as a State; however, it is disputable that Palestine meets the criteria of statehood. ${ }^{3}$

in Advancing Palestine's Actual Independence, "The Palestine Yearbook of International Law" 2013/14, vol. 17, p. 83.

3 On diverging views on the status of Palestine as a State, cf. L. Balmond, État palestinien, [in:] T. Garcia (ed.), 'La Palestine', supra, pp. 7 ff; J. Quigley, The Statehood of Palestine: International Law in the Middle East, Cambridge University Press, Cambridge 
Although the circumstances and facts relating to the conflict in the Middle East are generally known, we recall the most important factors of importance for the proceeding before the ICJ. ${ }^{4}$ After long negotiations, UNGA Resolution 181(II) of 29.11.1947 accepted the Plan of Partition with Economic Union. It foresaw a termination of the British mandate, gradual withdrawal of British military units from Palestine, establishment of Arab and Jewish States not later than 1.10.1948; division of Palestine into eight parts: three were allotted to the Arab State and three to the Jewish State; the seventh, the town of Jaffa, was to form an Arab enclave within Jewish territory. The international regime for Jerusalem, the eighth division, was proposed, subject to administration by the UN Trusteeship Council. The British mandate expired on 14.5.1948. On the same day, the Jewish Agency proclaimed the establishment of the State of Israel on the territory allotted to it by the partition plan. Violent hostilities immediately broke out between the Arab and Jewish communities, and Palestinian Arabs were supported by troops of neighbouring Arab States. At its third regular session, on 11.12.1948, the General Assembly adopted Resolution 194 (III), in which it proposed ways to resolve the Palestine problem, including a return of Palestinian refugees. The Assembly also called for the demilitarisation and internationalisation of Jerusalem and for the protection of, and free access to, the holy places in Palestine.

2010; J. Crawford, The Creation of the State of Palestine. Too Much Too Soon, "European Journal of International Law" 1990, vol. 1, no. 1, p. 307; P. Eden, Palestinian Statehood Trapped between Rhetoric and Realpolitik, "International and Comparative Law Quarterly” 2013, vol. 62, no. 1, p. 225; D. Momtaz, La controverse sur le statut de la Palestine, [in:] R. Wolfrum, M. Sersič, T. Šošič (eds.), 'Contemporary Developments in International Law. Essays in honour of Budislav Vukas', Martinus Nijhoff Publishers, Leiden-Boston 2016, p. 102; J. Salmon, La qualité de l'État palestinien, "Revue belge de droit international" 2012, no. 1, p. 13 and ff; M. Forteau, La Palestine comme État au regard du Statut de la Cour pénale internationale, "Revue belge de droit international" 2012, no. 1, pp. 9 and 41, respectively; among Polish writers, see E. Dynia, Uznanie państwa w prawie międzynarodowym [Recognition of the State in International Law], Wyd. Uniwersytetu Rzeszowskiego, Rzeszów 2017, pp. 248-260; A. Szarek-Zwijacz, „Państwo Palestyna” status prawny i aktywność Palestyny we wspótczesnych stosunkach międzynarodowych ["State of Palestine" - Legal Status and Activity of Palestine in Contemporary International Relations], [in:] J. Menkes, E. Cała-Wacinkiewicz (eds.), 'Państwo i terytorium w prawie międzynarodowym' [State and Territory under International Law], C.H. Beck, Warszawa 2015, pp. $490 \mathrm{ff}$.

4 See a description of facts by the ICJ in Legal Consequences of the Construction of a Wall in the Occupied Palestinian Territory advisory opinion, ICJ Rep. 2004, pp $165 \mathrm{ff}$. 
Between February and July 1949, under United Nations auspices, armistice agreements were signed between Israel, on the one hand, and Egypt, Jordan, Lebanon and Syria, on the other. The agreements accepted the establishment of the armistice as an indispensable step towards the restoration of peace in Palestine. They also clarified that the purpose of the armistice was not to establish or recognise any territorial, custodial or other rights, claims or interests of any party. The conflict was suspended and not resolved. Meanwhile, on 11.5.1949, Israel became a Member of the United Nations. In admitting Israel, the General Assembly considered Israeli declarations and explanations referring, among other things, to the international regime envisaged for Jerusalem, the problem of Arab refugees and boundary questions.

As a result of several Arab-Israeli wars (1967, 1973), Israel occupied a large portion of Palestinian territories. After years of military incidents, the parties concerned entered into negotiations which ended by a conclusion of the Oslo Accords between the Government of Israel and the Palestine Liberation Organization (PLO), signed in Washington in 1993, and in Taba, Egypt, in 1995. The Oslo process was aimed at concluding a peace treaty based on UNSC Resolutions 242 and 238, taking into account the right of Palestinian people to self-determination, resulting in the recognition by the PLO of the State of Israel and the recognition by Israel of the PLO as the representative of the Palestinian people and as a partner in negotiations. The Oslo Accords established a Palestinian Authority tasked with limited self-governance and accepted the PLO as Israel's partner in permanentstatus negotiations about the remaining questions (including borders of Palestine and Israel, Israel's military presence within the autonomy and the status of Jerusalem). The Oslo Accords, however, did not create a Palestinian State.

We present briefly the current factual situation of Palestine. There is no international consensus as to territorial sovereignty. In accordance with the Palestinian constitution, Palestine is composed of two districts: the Gaza Strip and West Bank, including East Jerusalem. These territories were occupied by Israel in 1967, and partially annexed, although the annexation was never recognised by the international community. UN agencies (at least since 1999) and the ICJ refer in their instruments ${ }^{5}$

5 Including the Advisory Opinion of 9.7.2004 on the Legal Consequences of the Construction of Wall in the Occupied Palestinian Territories, ICJ Rep. 136. Cf. P. O'Brien, Issues related to General Assembly resolution 67/19 on the status of Palestine in 
to the occupied Palestinian territories. In short, without entering into details, Palestine never exercised sovereign rights with respect to the areas referred to. The population consists mostly of Palestinians (ca. 3.8 mil, i.e. 95\% of the inhabitants), and Israeli settlers inhabiting special settlements, which are contrary to international law. The government is the Palestinian Unity Government (established in June 2014), based on a fragile agreement between two groupings: Fatah and Hamas. The effectiveness of the government is dubious.

The basis for our discussion is Article 3 and 4 of the UN Charter. Admission to the UN is restricted to States, i.e. entities which meet the criteria of statehood universally accepted under international law.

Article 1 of the 1933 Montevideo Convention on the Rights and Duties of States contains a universally accepted definition of statehood. A State as an international legal person should possess the following qualifications: (a) a permanent population; (b) a defined territory; (c) government; (d) capacity to enter into relations with the other States. This definition was repeated by the Badinter Commission" in Opinion No. 1: "the State is commonly defined as a community which consists of a territory and a population subject to an organized political authority; that such a state is characterized by sovereignty". There is a dispute as to what is a juridical classification of the definition; we share the opinion that it is a restatement of customary international law. The issue of statehood was extensively discussed in international legal writing. We could define it referring to the definition of a horse from „Nowe Ateny”, first Polish Encyclopaedia published in the mid-18 ${ }^{\text {th }}$ century: " what is the horse, everyone can see". The problem is that all elements of statehood are subjected to certain evaluation, and in many cases, the evaluation is based upon individual, subjective opinions.

the United Nations, http://palestineun.org/wp-content/uploads/2013/08/012-UN-Memoregarding-67-19.pdf; A. Kleczkowska, Status Palestyny w ONZ [Status of Palestine in the UN], "Ruch Prawniczy, Ekonomiczny i Socjologiczny" 2013, no. 1; Th. Garcia, Palestine au sein du système des Nations Unies, [in:] Th. Garcia (ed.), 'La Palestine', op. cit., p. 25.

6 The Arbitration Commission of the Conference on Yugoslavia (commonly known as the Badinter Arbitration Committee) was an advisory body set up by the Council of Ministers of the EEC in order to provide the Conference with legal advice. Opinion No.1 was issued on 29.11.1991.

7 The Encyclopaedia was dedicated: Mądrym dla Memoryału, Idiotom dla Nauki, Politykom dla Praktyki, Melancholikom dla Rozrywki [To the Wise for Memory, Idiots for Knowledge, Politicians for Practice, Melancholics for Fun]. 
Neither the Charter itself, nor two advisory opinions of the ICJ ${ }^{8}$ concerning the interpretation of the provisions of the Charter, clarified the notion of the State. ${ }^{9}$ In the application proceedings in 1946-1962, a number of reservations were invoked, in particular a lack of effective and independent government, but also the absence of defined borders (the case of Israel) or claims to the territory of the applicant by neighbouring States (Mauritania, Kuwait). References were also made to diplomatic relations and recognition. The criteria of statehood were applied arbitrarily, so that attempts were made to adopt objective elements of evaluation. However, the idea was finally abandoned. Notwithstanding, various authors have proposed additional criteria of statehood, e.g. independence, sovereignty, lack of claims to territory by third States, democracy, rule of law, etc., which, however, do not reflect current international law. ${ }^{10}$

Even if we accept that the criteria of statehood (both formulated in the Montevideo Convention and others) are legal norms, we have to ask what their real importance is. If they are met, they do not create a State. If they are not, that does not preclude an entity in question to become a State. If the criteria are met, they do not create an obligation of recognition; if not, is there an obligation not to recognise statehood? As to the former question, there is a consensus that there is no duty to recognise statehood. As to the latter, the obligation of non-recognition is limited to cases of violation of (peremptory) international law. ${ }^{11}$ Such an approach shifts the issue of creation of States towards recognition, which plays a dominant role in the process. ${ }^{12}$

8 Conditions of Admission of a State to Membership in the United Nations, ICJ Rep. 1948, p. 57; Competence of the General Assembly for the Admission of a State to the United Nations, ICJ Rep. 1950, p. 4.

9 See F. Tse-shyang Chen, The Meaning of "States" in the Membership Provisions of the United Nations Charter, 'Indian International and Comparative Law Review' 2001, vol. 12, no. 1, pp. $25 \mathrm{ff}$.

10 Th.D. Grant, The Recognition of States: Law and Practice in Debate and Evolution, Westport CT, Praeger, London 1999; E. Wyler, Théorie et pratique de la reconnaissance d'État. Une approche épistémologique du droit international, Éditions É. Bruylant, Bruxelles 2013.

11 J. Vidmar, Democratic Statehood in International Law. The Emergence of New States in Post-Cold War Practice, Hart Publishing, London et al. 2013, emphasises that: "States do not emerge automatically from the application of legal criteria but of a political process whereby a declaration of independence is accepted" (pp. 63; 137; 238-241).

12 According to him, such acceptance can take several forms: consent by the parent State, dissolution of the parent State, internationalised action and 'constitutive recognition'. All these institutions are simply various forms of recognition. 
Actually, constitutive or declarative conceptions are no longer adequate, as they do not answer many questions and objections. There is no unambiguous answer that has more meaning or is more convincing. For many years, the view of the declarative nature of recognition prevailed, but the thesis of a constitutive nature seems consistently very widespread. ${ }^{13}$ Contemporary authors try to avoid the question of the nature of recognition, indicating that recognition usually combines declarative and constitutive features. ${ }^{14}$

The constitutive concept of recognition is particularly striking in cases of collective recognition. The notion of collective recognition is often referred to in legal writing; however, there is no uniform definition. Two interpretations are possible. The first covers recognition by a group of States (or - in an ideal model - by all States, i.e. the international community as a whole), acting together or simultaneously (a notion of a concerted practice can be proposed). ${ }^{15}$ In such case, in principle, third countries act separately, individually, fulfilling their political or legal obligations. The second interpretation, on the other hand, concerns recognition made within an international organisation (we may consider whether a similar function is not fulfilled by joining an open multilateral agreement, although we are not convinced of this - we shall go back to that point elsewhere). Recalling the example of Palestine: the first situation involves granting Palestine the status of a Non-Member State observer to the UN, while the second is the accession of Palestine to multilateral international agreements (including The Hague and Geneva Conventions on the law of war and humanitarian law), but also to UNESCO or to the ICC.

13 See S. Talmon, The Constitutive versus the Declaratory Theory of Recognition: Tertium Non Datur?, "British Yearbook of International Law” 2005, vol. 75, p. 101.

14 See recently ILA Conference Sydney 2018, $4^{\text {th }}$ (Final) Report of the Committee on Recognition/Non-Recognition, and the Resolution of the Conference, http://www.ila-hq. org/images/ILA/Resolution`s/ILAResolution_3_2018_RecognitionNon-Recognition. pdf.

15 The recognition of States in the territory of former Yugoslavia on the basis of the 1991 Guidelines of the European Political Cooperation on Recognition of new States, or the recognition of Kosovo (which is less representative) could be examples. 


\section{The status of Palestine within the UN}

In 1974, the General Assembly adopted Resolution 3237 (XXIX), inviting the Palestine Liberation Organization (PLO) to participate as an observer. Observer status allows limited participation rights in the UN for nonmember States, (mostly regional) intergovernmental organisations and institutions, groups of States and, in the first decades of the UN, national liberation movements. It enables non-member States an opportunity to contribute to UN activities (according to the universality principle) and - on the other hand - to profit from the specific knowledge and experience of all possible entities, as well as disseminating the acquis of the UN. Currently, there are three categories of observers: non-member States (Holy See and Palestine, the status of both being disputable; potential candidates are Taiwan, Kosovo, Somaliland and Western Sahara), intergovernmental organisations and institutions and national liberation movements (at present, no national liberation movement is listed as an observer).

In December 1988, following the Palestinian National Council's declaration of the independence of Palestine, the UN General Assembly decided that the designation 'Palestine' should be used in place of the designation 'Palestine Liberation Organization' in the United Nations system. Step by step, the General Assembly has increased the scope of this participation to the point where Palestine's status became practically identical to that of an observer State.

On 29.11.2012, the UNGA adopted by a majority of 138 votes to 9 against and 41 abstentions, with 5 States not voting, Resolution $\mathrm{A} / \mathrm{RES} / 67 / 19$, granting to Palestine the status of non-member observer State. ${ }^{16}$ In the Resolution, the General Assembly, inter alia,

reaffirmed the right of the Palestinian people to self-determination and to independence in their State of Palestine on the Palestinian territory occupied since 1967 and decided to accord to Palestine non-member observer State status in the United Nations, without prejudice to the acquired rights, privileges and role of the Palestine Liberation Organization in the United Nations as the representative of the Palestinian people, in accordance with the relevant resolutions and practice. 
The resolution also "expressed the hope" that the Security Council would consider favourably the application submitted on 23.9.2011 by the State of Palestine for admission to full membership in the United Nations and "urged all States, the specialized agencies and organizations of the United Nations system to continue to support and assist the Palestinian people in the early realization of their right to self-determination, independence and freedom". The resolution itself did not grant new rights to Palestine as to participation in the UN system, and it is mostly symbolic.

Among the States voting against the Resolution, one mentions, e.g. Israel, USA, Canada and Czechia; most EU member States, including Poland and Germany, abstained. The decision of the UNGA was sharply criticized by Israel, who stated that the only way to establish the Palestinian State is direct negotiations between Jerusalem and Ramallah, and not through legal tricks in international organisations. This position was supported by a number of States.

The granting of the status of an observer State entails the consequences of recognising Palestine as a State for the purposes of United Nations law, in particular for the practice of the Secretariat and the General Assembly, at least for administrative purposes. According to the usage, Palestine informed the UNSG of the name "State of Palestine" for the use in the UN system. However, the notion of occupied Palestinian Territories should be used to designate the whole geographical area of Palestine. Palestine is able to participate in the work of the UNSC relating to the disputes it is a party to. The UN Secretary-General confirmed having adopted this position in his capacity as treaty depositary. He has accepted as valid a number of treaty actions (accession to at least 15 treaties in February $2014)^{17}$ on behalf of Palestine since the adoption of the Resolution, and there has been protest from only a handful of States. The UNSG practice was followed by the governments of the Netherlands and Switzerland as to The Hague and Geneva Conventions on the law of war and humanitarian law. However, those conventions are aimed at gaining the widest possible participation, and they cannot be conclusive as to cure any deficiency in Palestine's meeting of the Montevideo criteria. It is disputable whether they can confer or confirm the international legal personality.

The accession to multilateral treaties poses a question concerning the role of depositaries in resolving disputes as to the status of the parties.

17 The list of treaties binding upon Palestine can be consulted at: https://ihl-databases. icrc.org/applic/ihl/ihl.nsf/vwTreatiesByCountrySelected.xsp?xp_countrySelected=PS. 
States attach importance to the purely administrative role of the depositarywhich is, in particular, visible with respect to the reservations to multilateral treaties. In our opinion, there is no obstacle in applying practice concerning reservations to other notifications. In accordance with the principle of the "letter box depositary", endorsed by Article 77 of the 1969 Vienna Convention, in principle, the depositary can only take note of instruments of which it has been notified and transmit them to the contracting States without ruling on their permissibility, i.e. it cannot reject an instrument of accession by reference to the unclear status of the entity presenting the instrument concerned. It can only examine whether the signature or any instrument, notification or communication relating to the treaty is in due and proper form and, if need be, bring the matter to the attention of the State in question for their decisions. A proposal by the Commission that would have conferred upon the depositary a more active role in relation to reservations failed at the 1969 session of the Vienna Conference. Similarly, a proposal for such a role within the guidelines as provisionally adopted was not pursued in the face of opposition in the Sixth Committee. ${ }^{18}$ The practice of the UNSG as depositary cannot be conclusive as to the international legal status of Palestine as a State. On the other hand, current practice shows that States protest against instruments they do not accept as lawful.

It is highly probable that the accession of Palestine to the UN based upon a decision of the UNSC would have an erga omnes effect. In the case of the United Nations, an application for membership would be a test of statehood. In September 2011, Abbas, acting on behalf of Palestine, unsuccessfully applied for UN membership. The US veto in the UNSC makes the accession difficult, if not impossible.

In conclusion, we are of the opinion that it is subjected to debate whether GA Resolution 67/19 may be viewed as sufficient collective recognition to resolve any defect in Palestine's fulfilment of the Montevideo criteria, and hence to establish its statehood and capacity to consent to ICC jurisdiction. While the number of "yes" votes comprises more than twothirds of UN Member States, we do have reasonable doubt as to whether

18 See Guide to Practice on Reservations to Treaties, http://legal.un.org/ilc/ reports/2011/english/addendum.pdf, pp. $160 \mathrm{ff}$, and M. Wood, Institutional Aspects of the Guide to Practice on Reservations, "European Journal of International Law" 2013, vol. 24, no. 4, p. 1103 ff. In a similar vein, see also O. Corten, P. Klein (eds.), The Vienna Convention on the Law of Treaties. A Commentary, vol. 1, Oxford University Press, Oxford 2011, pp. $1732 \mathrm{ff}$. 
this is sufficient collective recognition to be essentially constitutive of Palestine's statehood. Moreover, it is also disputable whether the criteria of statehood play any role in the process of evaluation of statehood, and this process is purely political.

The status of Jerusalem is another important element of the puzzle. There are indications that Israel itself is not convinced as to the situation of the area. The partition plan provided that the city of Jerusalem did not form part of the two Independent States that were supposed to be created in Palestine. Thus, the status of Jerusalem was a corpus separatum $a b$ ambis statis subjected to a special international regime, established by UNGA Resolution 181(II) of 29.11.1947. The special status was confirmed by the Oslo Agreement, according to which the status of East Jerusalem should be regulated by an agreement between Israel and Palestine. The city of Jerusalem cannot be declared to be the capital of either State: neither the State of Israel nor the State of Palestine.

Two important resolutions of the UNSC concerned Jerusalem and the status of diplomatic missions. Resolutions 476 and 478, adopted on 30.6.1980 and 20.8.1980, respectively, were a reaction to the adoption by the Knesset of the law establishing Jerusalem as the entire and undivided capital of Israel. In particular, they pointed to the obligation not to recognise illegal situations, condemned the rejection by Israel of the order to withdraw from the occupied territories and emphasised that all legislative and administrative measures and actions taken by Israel, the occupying power, which have altered or purport to alter the character and status of the Holy City of Jerusalem, and in particular the "basic law" on Jerusalem, were null and void. All Member States should accept and exercise the resolution. In particular, those States that have established diplomatic missions in Jerusalem should withdraw such missions from the Holy City. Although the Resolutions did not expressly referred to Chapter VII, they were respected, as all States moved their missions to Tel Aviv and neighbouring localities. This status quo continued till May 2018.

Although Israel does not claim exclusive sovereignty over East Jerusalem, ${ }^{19}$ it accepted the functioning of ca. 10 consulates generals (e.g. UK, Belgium, Sweden, Spain and the Holy See), which are accredited

19 In the discussion on the implementation of the UNGA resolution 194(III), Israel was of the opinion that the status of Jerusalem was not clearly defined, and Israel did not intend to determine it unilaterally. The stance of the Israeli government did not change. 
neither to Israel nor to the Autonomy. The status of those institutions is different than the status of diplomatic and consular missions situated in Israel. Finally, there is a dispute as to certain facts: some observers ${ }^{20}$ stress that the US Embassy is, in reality, situated in West Jerusalem, in the territory belonging to Israel. Other commentators situate it is in an area of a specific no-man's land. Such a localisation of the embassy does not signify the recognition of Israeli sovereignty over East Jerusalem.

All the Resolutions mentioned above directly concerned activities of the diplomatic missions in Jerusalem. Numerous other instruments adopted by the political organs of the UN concerned the status of Jerusalem, e.g. the UNSC, in the unanimously adopted Resolution 242 of 22.11.1967, which played a key role in defining the situation in the Middle East, called on Israel to withdraw its armed forces from territories occupied in the 1967 conflict; Resolution 251 of 2.5.1968 condemned Israel holding its military parade in Jerusalem; Resolution 252 of 21.5.1968 asked Israel to cancel all activities in Jerusalem and condemned the occupation of any land through armed aggression, and it also demanded Israel "desist from taking any further action which tends to change the status" of the city; Resolution 298 of 25.9.1971 confirmed that all actions taken by Israel to change the status of Jerusalem, such as land confiscation, were illegal; Resolution 465 of 1.3.1980 demanded Israel to stop the planning and construction of settlements in territories occupied since 1967, including Jerusalem, and to dismantle the existing settlements; Resolutions 271(1969) of 15.9.1969, 672(1990) of 12.10.1990, 1073(1996) of 28.9.1996 and 1322(2000) of 7.10.2000 concerned different incidents at the Al-Aqsa Mosque, which resulted in a number of civilian deaths. Other Resolutions referred to Israel as an "occupying power". Resolution 2334 of 23.12.2016 condemned Israel's construction of settlements in all territory occupied since 1967, including East Jerusalem, and stated that they have no legal validity and constitute a flagrant violation under international law. The UNSC emphasised it would not recognise any changes to the 4.6.1967 lines, including with regard to Jerusalem, other than those agreed upon by the parties through negotiations and stressed that the "cessation of all Israeli settlement activities is essential for salvaging the two-State solution". It also called upon all States to distinguish, in their relevant

20 Cf. David Hughes, http://www.qil-qdi.org/us-embassy-jerusalem-location-matter/ (accessed: 24.1.2019) 
dealings, between the territory of the State of Israel and the territories occupied since 1967.

On 18.12.2018, the USA vetoed a draft resolution sponsored by Egypt. Fourteen of the Council's 15 members, including close allies like Britain, France and Japan, voted in favour of a resolution that would have declared that any unilateral decisions regarding the status of Jerusalem "have no legal effect, are null and void and must be rescinded". On the same day, the General Assembly voted overwhelmingly during a rare emergency meeting to ask nations not to establish diplomatic missions in the historic city of Jerusalem, as delegates warned that the recent decision by the United States to do so risked igniting a religious war across the already turbulent Middle East and even beyond. By a recorded vote of 128 in favour to 9 against (Guatemala, Honduras, Israel, Marshall Islands, Federated States of Micronesia, Nauru, Palau, Togo, the United States), with 35 abstentions, the Assembly adopted Resolution ES10/L.22 "Status of Jerusalem", by which it declared null and void any actions intended to alter Jerusalem's character, status or demographic composition. Calling on all States to refrain from establishing embassies in the Holy City, it also demanded that they comply with all relevant Security Council resolutions and work to reverse the negative trends imperilling a two-State resolution of the Israeli-Palestinian conflict.

Resolution ES-10/L.22 is not unique in UNGA practice. We refer also to Resolution 2253 of 4.7.1967, which expressed concern at Israel's attempts to change the status of Jerusalem and called for "all measures already taken" to be rescinded and there should be no further such action. Resolution 36/15 of 28.10.1981 determined that Israel's transformation of Jerusalem, including historical, cultural and religious sites, constituted a "flagrant violation of the principles of international law". Such acts, the resolution stated, "constitute a serious obstruction to achieving a comprehensive and just peace in the Middle East". Resolution 55/130 of 28.2.2001 demanded that Israel cooperate with a special committee set up to "investigate Israeli practices affecting the human rights of Palestinian people and other Arabs" in the occupied territories. The Resolution expressed "grave concern" about the situation in Jerusalem "as a result of Israeli practices and measures... [especially] the excessive use of force... which has resulted in more than 160 Palestinian deaths". Resolution 70/89 of 15.12 .2015 condemned the continuation of Israeli occupation of the Occupied Palestinian Territory, including East Jerusalem, as a violation of international law. The Resolution also denounced Israel's "unlawful construction" of a wall inside occupied territories, "including in and around East Jerusalem". 
Finally, we address the resolutions adopted within the framework of UNESCO, including Resolution 150 of 27.11.1996, declaring that the "Old City of Jerusalem" was inscribed on the endangered world heritage list and labelling Israel's opening of an entrance to a tunnel near the alAqsa Mosque as "an act which has offended religious sensibilities in the world". Resolution 184 of 2.4.2010 expressed deep concern regarding Israeli archaeological works, including excavations, at the al-Aqsa Mosque compound in Jerusalem. The Resolution stated that the works "contradict UNESCO decisions and conventions". Resolutions 196 (22.5.2015) and 202 (18.11.2017) expressed deep regret at Israel's "refusal to implement previous UNESCO decisions concerning Jerusalem".

Summing up, all these acts confirmed the status of East Jerusalem (and other territories occupied by Israel), condemned Israel's unilateral actions, underlined the non-compliance with international law of such acts and called for abandoning violations and not recognising their consequences. Non-compliance with UN acts and international law was raised in discussions in the Security Council and UNGA on the occasion of resolutions related to the transfer of the US embassy to Jerusalem. In this context, the authors draw attention to the issue of the obligation not to recognise unlawful situations in international law. ${ }^{21}$ In the context of the situation of Palestine, the issue was discussed, in particular, by

21 In the context of Palestine, see M. Arcari, The relocation of the US embassy to Jerusalem and the obligation of non-recognition in international law, "Questions of International Law" 2018, Zoom-in 50, p. 1; A. Lagerwall, The non-recognition of Jerusalem as Israel's capital: A condition for international law to remain relevant?, "Questions of International Law" 2018, Zoom-in 50, p. 33. Cf. also S. Talmon, The Duty not to "Recognize as Lawful" a Situation Created by the illegal Use of Force or Other Serious Breaches of a Jus Cogens Obligation: An Obligation Without Real Substance?, and Th. Christakis, L'obligation de non-reconnaissance des situations créées par le recours illicite à la force ou d'autres actes enfreignant des règles fondamentales, [in:] Ch. Tomuschat, J-M. Thouvenin (eds.), 'The Fundamental Rules of the International Legal Order', Martinus Nijhoff Publishers, Leiden-Boston 2006, p. 99 and 127, respectively. See A. Pert, The 'Duty' on Non-Recognition in Contemporary International Law: Issues and Uncertainties, 'Chinese (Taiwan) Yearbook of International Law \& Affairs' 2012, vol. 30, pp. 60-63; E. Milano, The Doctrine(s) of Non-Recognition: Theoretical Underpinnings and Policy Implications in Dealing with De Facto Regimes, “ESIL Research Forum” 2007, www.esilsedi.eu/fichiers/en/Agora_Milano_060.pdf; W. Czaplinski, The Crimean crisis and the Polish practice on non-recognition, "Questions of International Law" 2014, Zoom-out I , pp. 73-84. 
the ICJ in the Wall in the Palestinian Territory advisory opinion. ${ }^{22}$ The opinion by the ICJ dealt with the whole situation accompanying the construction of the wall, which was indirectly substantial for our considerations, and declared that:

Given the character and the importance of the rights and obligations involved, the Court is of the view that all States are under an obligation not to recognize the illegal situation resulting from the construction of the wall in the Occupied Palestinian Territory, including in and around East Jerusalem. They are also under an obligation not to render aid or assistance in maintaining the situation created by such construction. It is also for all States, while respecting the United Nations Charter and international law, to see to it that any impediment, resulting from the construction of the wall, to the exercise by the Palestinian people of its right to self-determination is brought to an end. In addition, all the States Parties to the Geneva Convention relative to the Protection of Civilian Persons in Time of War of 12 August 1949 are under an obligation, while respecting the United Nations Charter and international law, to ensure compliance by Israel with international humanitarian law as embodied in that Convention. Finally, the Court is of the view that the United Nations, and especially the General Assembly and the Security Council, should consider what further action is required to bring to an end the illegal situation resulting from the construction of the wall and the associated regime, taking due account of the present Advisory Opinion. ${ }^{23}$

However, because of doubts as to the situation of the US embassy, we do not analyse this aspect of the matter.

\section{Palestine's Membership to the International Criminal Court}

The ICC is not a UN body, so from a formal point of view, the requirements defining the definition of a State do not apply to it. The ICC Statute is open to all States. International law draws a distinction between Signatory States, Contracting States and State Parties. A Signatory State is a State that has signed a treaty. A Contracting State is a State that has completed

22 Legal Consequences of the Construction of a Wall in the Occupied Palestinian Territories, advisory opinion, ICJ Rep. 2004, p. 136.

${ }^{23}$ Ibidem, p. 200, paras. 159 and 160. 
its expression of consent to be bound. A State Party is a State for which the treaty has entered into force. According to its Article 125, the Rome Statute was open for signature for a limited time only (i.e. until 31.12.2000). After that date, States can become parties to the Statute by accession.

In the beginning of 2009, the Palestinian Authority lodged with the ICC Registrar a declaration recognising the jurisdiction of the ICC with respect to crimes committed in the territory of Palestine since 1.7.2002. The ICC Prosecutor, L. Moreno Ocampo, reported that he was examining "whether the declaration accepting the exercise of jurisdiction by the Court meets statutory requirements". The phrase "statutory requirements" presumably includes the question of whether or not Palestine is a "State" for the purposes of Article 12(3). ${ }^{24}$

On 12.4.2012, the Office of the Prosecutor of the ICC released a statement indicating that it, for the moment, would not be considering allegations of crimes committed in Palestine. The analysis referred, inter alia, to the practice of the UN Secretary-General as treaty depositary and noted, in particular, that the then current status granted to Palestine by the United Nations General Assembly was that of observer, not as a nonmember State.

The Prosecutor's reference to the treaty practice of the United Nations may add some weight to the significance of the UNESCO and General Assembly votes. As with UN membership, the issue of treaty participation is distinct from the question of statehood. Negotiating States can decide to make treaty participation available to entities other than fully independent or UN Member States. Even where the text of a treaty limits

24 See V. Azarova, Tell It to the Judge: Palestine's UN Bid and the International Criminal Court, [in:] M. Qafisheh (ed.), 'Palestine Membership in the United Nations: Legal and Practical Implications', Cambridge Scholars Publishing 2013, p. 252; Y. Ronen, Israel, Palestine and the ICC: Territory Uncharted but not Unknown, "Journal of International Criminal Justice" 2014, vol. 12, no. 1, p. 7; A. Zimmermann, Palestine and the International Criminal Court quo vadis? Reach and limits of declarations under Article 12(3), "Journal of International Criminal Justice" 2013, vol. 11, no. 2, p. 303; A. Pellet, The Effects of Palestine's Recognition of the International Criminal Court's Jurisdiction, [in:] Ch. Meloni (ed.), 'Is there a Court for Gaza?', T.M.C. Asser Press, The Hague 2012, p. 409; S. Høgestøl, Palestinian Membership of the ICC: A Preliminary Analysis, "Nordic Journal of Human Rights" 2015, vol. 33, no. 3, p. 193; B. Krzan, Trudne początki palestyńskich relacji z Międzynarodowym Trybunałem Karnym, [Difficult Beginnings of Palestinian Relations with the International Criminal Court] [in:] 'Państwo i terytorium' [State and Territory], op. cit., p. 344 . 
participation to States (as does the ICC Statute), there may be a grey area in which the treaty depositary is afforded a degree of discretion.

While the ICC is not a UN organ, and not legally bound by the General Assembly resolution as such, ICC officials have shown deference to the UN position. For example, the President of the ASP, upon receipt of the SecretaryGeneral's notification of accession, "welcomed the deposit by the State of Palestine of the instruments of accession to the Rome Statute". The ICC Registrar's letter addressed to the "President of the State of Palestine", in which he states that he "hereby accept[s] the [Article 12(3)] declaration" is dated 7.1.2015 - the day after the Secretary-General's notification. Finally, according to a press release issued on 16.1.2015 announcing the opening of the preliminary examination into the situation in Palestine, "for the Office [of the Prosecutor], the focus of the inquiry into Palestine's ability to accede to the Rome Statute has consistently been the question of Palestine's status in the UN, given the UNSG's role as treaty depositary of the Statute". UNGA Resolution 67/19 is therefore determinative of Palestine's ability to accede to the Statute pursuant to Article 125 and, equally, its ability to lodge an Article 12(3) declaration.

Ultimately, it would be up to the Court itself to determine the scope and validity of its jurisdiction. In principle, the issue should be decided upon the basis of applicable rules of international law, in the application of which the General Assembly resolution, and subsequent practice, will be a major factor.

In the first days of January 2015, Palestinian leader Mahmoud Abbas attempted to take two treaty actions with respect to the Rome Statute of the ICC. The first was to deposit with the UN SecretaryGeneral a document purporting, on behalf of the State of Palestine, to be an instrument of accession to the Rome Statute. The second was to lodge with the ICC Registrar a document purporting to accept the Court's jurisdiction retrospectively to 13.6.2014. From the perspective of our considerations, the former instrument is of great importance. According to the depositary notification circulated by the UN Secretary-General on 6 January, the Rome Statute will enter into force for Palestine on 1.4.2015, at which point it would be deemed a State Party. This raises the question of the authority of the Secretary-General to make this determination and, assuming he has such authority as necessary to carry out his functions as depositary, whether this determination has legal force beyond the scope of those functions. The following day, the President of the ICC Assembly of States Parties welcomed the accession, and the ICC Registrar sent a letter to Abbas accept [ing] the declaration. 
On 16 January, Canada, Israel and the United States communicated their protests to the UN Secretary-General in his capacity as treaty depositary (Israel and the US are signatories to the Rome Statute. Canada is a State Party. $)^{25}$

According to that understanding, "the Secretary-General, in discharging his functions as depositary of a convention with an 'all States' clause, will follow the practice of the Assembly in implementing such a clause and, whenever advisable, will request the opinion of the Assembly before receiving a signature or an instrument of ratification or accession". The OTP essentially used this understanding as a justification for punting the issue to the political organs of the United Nations, stating that "it is for the relevant bodies at the United Nations or the Assembly of States Parties to make the legal determination whether Palestine qualifies as a State [...]".

In any event, the General Assembly has finally determined that Palestine is a State by granting a modified non-member observer State status. Given the OTP's reliance on the practice of the Secretary General as treaty depositary and, in turn, on determinations by the competent organs of the United Nations, and by the General Assembly in particular, it would now seem more difficult for the OTP to maintain the position that it may not proceed with an examination of international crimes alleged to have been committed in Gaza and the West Bank. The pressure on the OTP to move forward will further increase if the situation in Palestine is referred to the OTP by a State Party to the ICC Statute.

25 According to Canada's communication, it is not for the Secretary General to determine any legal issues raised by the legal instruments circulated (presumably whether Palestine is a State and thus whether the accession is legally effective). The communication continues by asserting that Palestine fails to meet the criteria for statehood and noting Canada's position that Palestine cannot accede to the Rome Statute and that the treaty will not enter into force for Palestine. This could raise complicated issues in relation to the administration of the Assembly of States Parties, State Party cooperation, financing and elections. Presumably, matters concerning the Court's jurisdiction will be finally determined by the Court, and Canada would be bound to cooperate in relation to such matters. But whether a Court finding on the statehood issue would be binding on the States Parties for all purposes is arguably a separate issue. The communications issued by the US and Israel similarly indicate their positions that Palestine is not a State and is thus unable to accede to the Rome Statute. Palestine has responded to the protests of all three States with communications asserting its statehood and its intention to exercise its rights and honour its obligations with respect to all States Parties. 
Shortly thereafter, on 31.10.2011, Palestine was admitted to the United Nations Educational, Scientific and Cultural Organization (UNESCO), a specialised agency, as a Member State and subsequently became a party to several UNESCO treaties.

Both modifications of the status of Palestine were opposed by a group of States, and they could not lead towards stablishing of the State of Palestine, opposable to all States within the international community.

Palestine is recognised as a State by some 140 countries, but - unlike Kosovo, which runs a dedicated website - it is not possible to determine exactly who actually made the recognition. Interestingly, Palestinian passports are, in turn, recognised only by a small group of States, ${ }^{26}$ which shows an inconsistency of the recognising States - the political declaration is something else, and the real policy requirements (including international and internal security) are something else. Some of the countries recognised Palestine within the limits of 4.6.1967, including East Jerusalem $;{ }^{27}$ however, the majority did not report on border issues. A State does not have to have precisely defined external borders for its existence - although it should, however, somehow control them. The territory of the new State should contain key areas that determine the separateness in relation to other countries. It must be assumed that East Jerusalem is one of such key areas - but it is equally important to Israel. In the interwar period, Lithuania considered Vilnius as its capital city (although its status as part of the Polish State was not questioned by the international community, including the League of Nations), at the same time defining Kaunas as the seat of the government. Territorial claims - let us remind you - do not create a legal title to the territory. An important problem when it comes to the statehood of Palestine is the population. As mentioned above, Palestinian passports are generally not recognised, and this leads to the conclusion that citizenship of Palestine is not recognised. It is citizenship that is the link between the inhabitants of a particular territory and the State. Added to this is the unresolved and controversial issue of Palestinian refugees residing in various Middle East countries. Finally, the powers of the Palestinian Authority (government) and its international position are equally disputable. Notwithstanding many efforts by Palestine,

26 L. Balmond, État palestinien, op. cit., p. 9.

27 V. Kattan, Palestine declares (legal) war on the United States of America, http:// victorkattan.com/work/haaretz-publishes-my-take-on-palestine-v-united-states-ofamerica/ (accessed: 2.1.2019). 
it would be unrealistic to call it a State. If recognition can create statehood, we are confronted with a nightmare: Palestine is a State for some States, but not for others.

The settlement of the status of Palestine requires an indication of what it is - if it is not a State. The notion of a State in statu nascendi does not decide anything (except that Palestine is not a State). The mandate has expired. It is not terra nullius (even considering the criteria indicated by ICJ in the 1975 advisory opinion on Western Sahara).

A certain analogy to Germany after the Second World War can be drawn. The German State (as a regime: the Third Reich) ceased to exist, and the highest power in Germany was taken over by four occupying powers, which, however, clearly stressed that they have no intention of annexing the territory of the Reich. All in all, it was - from a historical perspective the typical fate of an occupied State. The dispute about the legal situation of Germany lasted for the post-war period from the unconditional surrender on 8.5.1945 to the unification of Germany on 3.10.1990. The situation of Palestine can be evaluated ex post in the same way - in the sense that only a lapse of time will resolve the problem.

\section{Assessment of the position of Palestine in a possible proceeding before the ICJ}

Palestine in its application indicates that the Vienna Convention on Diplomatic Relations (VCDR) refers in many places (e.g. in Article 3, regarding the function of diplomatic missions) to conducting activities and contributing to the development of relations between the sending State and the receiving State. This formula only defines the substantive scope of competence of diplomatic missions and in no way limits the activities of the mission to the territory of the host country. Of course, the standard practice is to situate missions on the territory of the host country, usually in its capital or seat of government, but this is not an absolute requirement. In principle, with some exceptions, diplomatic law does not require a diplomatic representation to be in a specific place on the territory of a given State. We do not discuss the qualitatively different issue of multiple representation of the sending State to more than one receiving State.

This practice leads us to the following conclusion. The individual elements of the definition of a State have different meanings, depending on the context in which we refer to it. Typically, the most important is the territory 
of the State, determining the scope of rights and obligations. In the case of diplomatic law, however, the element of State power is of fundamental importance. Diplomatic relations have no territorial reference, but they concern the State as a subject of international law (in a sense, it is an abstract function). ${ }^{28}$ The VDCR, in principle, does not deal with territorial issues, with the exception of the provision of Article 12 ("The sending State may not, without the prior express consent of the receiving State, establish offices forming part of the mission in localities other than those in which the mission itself is established"). Understood literally, this provision makes the setting up of facilities forming part of the diplomatic mission in a location (locality) different from the seat of the mission. In our case, this provision is irrelevant, since the headquarters of the American embassy was agreed upon with the Israeli authorities. Israeli consent is decisive.

The practice of representation of States at international organisations also indicates a diverse policy of host countries regarding the location of the institution. Switzerland strongly refuses to represent sending countries at organisations based in Geneva by diplomatic missions accredited in Bern; a similar practice was adopted by the USA in relation to diplomatic missions in Washington and the UN mission in New York. Italy, on the other hand, does not take issue in the case of diplomats carrying out a mission in the Italian Republic accredited by organisations based in Rome. Of course, we must take into account the differences resulting from the geographic location of these facilities.

Another issue is debatable: does Palestine have procedural legitimacy to start proceedings? This problem will have to be considered by the Court in the jurisdictional phase. It is hard to imagine that the US would ignore the lawsuit and refuse to take part in the proceeding, and they will certainly present preliminary exceptions, such as questioning Palestine's statehood and thus its procedural legitimacy.

However, in connection with the Palestinian motion, the United States made a statement to the depositary undermining the nature of Palestine as a State and denying the existence of a legal relationship between the US and Palestine based on $\mathrm{VCDR}^{29}$ :

28 Consular relations are of a different nature. Consuls exercise their functions in the defined area, which can cover the whole territory of the State or its part.

${ }_{29}$ Optional Protocol to the Vienna Convention on Diplomatic Relations, Concerning the Compulsory Settlement of Disputes, Vienna, 18.4.1961, https://treaties.un.org/doc/ Publication/CN/2018/CN.228.2018-Eng.pdf. 
The Government of the United States of America recalls that the Secretary-General in his depositary capacity issued, on April 9, 2014, a notification concerning accession by the 'State of Palestine' to the Vienna Convention on Diplomatic Relations, in response to which the United States Mission to the United Nations, on May 13, 2014, communicated that the Government of the United States of America believes that the 'State of Palestine' is not qualified to accede to the Convention. Therefore, the Government of the United States of America believes that the 'State of Palestine' is not qualified to accede to the Optional Protocol and affirms that it will not consider itself to be in a treaty relationship with the 'State of Palestine' under the Optional Protocol.

This does not change the fact that the ICJ in the American Hostages in Tehran case pointed out that obligations in the field of diplomatic law are vital and fundamental obligations, essential for the functioning of the international community. The verdict of 1979/1980 concerned the inviolability of the premises of the embassy, as well as diplomatic and consular personnel, i.e. a matter of fundamental importance for the diplomatic mission to perform its functions. The Court referred indirectly to the construction of jus cogens. It should be remembered that this was a very bold and innovative solution at the time. Certainly, on the basis of contemporary international law, the institutions of peremptory norms and erga omnes must be distinguished. The basis for such a distinction is, in particular, ILC Articles on the international responsibility of States for internationally wrongful acts (ARSIWA). They point, on the one hand, to mandatory norms, which, in the case of serious violation, may be the basis for special (strict) responsibility (even if it is illusory from the point of view of both substance and procedure). On the other hand, they define the procedure of accountability in case of violations of erga omnes norms, in particular, they indicate States that can claim responsibility of the perpetrator of a prohibited act.

Let us consider the last question. Article 42 ARSIWA provides that a State may be in a state of affairs. Therefore, the procedure of the Vienna Convention could be initiated by Palestine if we prove that it was harmed by the American act of recognising Jerusalem as part of Israel. However, during the UNSC discussion, it was also confirmed that the international community is not consistent with the legal status of East Jerusalem. Doubts equally concern the incorporation of Jerusalem into Israel and the Palestinian Authority. The mere submission of a claim by Palestine does not prejudge the existence of a legal title to Jerusalem. 
Palestine is decisively the third party (we do not deliberately call it a third State). According to Article 48 ARSIWA, any State other than an injured State ${ }^{30}$ is entitled to invoke the responsibility of another State if the obligation breached is owed to the international community as a whole.

A third party could therefore possibly present claims against a breach of law if the violation would concern an obligation erga omnes. As already indicated above, the obligations under the VCDR are not erga omnes obligations, and third countries cannot assert claims for infringement. Of course, we realise that in the background of the dispute about the violation of the VCDR, there is another issue entirely. The real reason for filing a complaint is the accusation of unlawful US recognition of the illegal annexation of East Jerusalem and other Arab territories to Israel. It seems, however, that the ICJ - so far abstemious in taking up disputable issues related to international politics - should not attempt to formulate a decision that was not submitted to it by the applicant. This is indicated, for example, by the proceedings regarding the advisory opinion on the declaration of independence of Kosovo. ${ }^{31}$

However, we can interpret the situation concerning claims based on the VCDR in a different way, not invoking issues of international claims based on ARSIWA. In accordance with Article 60 of the Vienna Convention on the Law of Treaties, in case of a material breach of the treaty, a party especially affected by the breach can invoke it as a ground for suspending the operation of the treaty. Parties which are not specially affected can invoke the breach as a ground for suspending the operation of the treaty in whole or in part if the violation radically changes the position of those parties with respect to the further performance of their obligations under the treaty. In the case concerned, there is no material breach of the treaty. We also submit that Optional Protocol No. 5 as lex specialis excludes the application of Article 60. Finally, the suspension of the VCDR is not in the interest of any party.

The Court applied so far at least several times a kind catwalk in order to avoid issuing a decision on merits of a dispute. The principle of Monetary Gold was formulated by the ICJ in a judgment on 15.6.1954 in a dispute between Italy, on the one hand, and Great Britain, France and the US, on the other. The subject of the dispute was the fate of gold owned by

30 Former versions of the Articles referred to notions of directly and indirectly injured States, which would be very useful in the context of the present case.

31 Advisory opinion of 22.7.2010, p. 403. 
the national bank of Albania, plundered by Germany in Rome in 1943. In accordance with an arrangement concluded at the Paris Conference on German reparations (14.1.1946), gold found in Germany should be returned in proportional shares to the States concerned. In the case of Albania, however, difficulties appeared in connection with two issues: claims by some States (in particular Italy) resulting from nationalisation of the National Bank of Albania, and a compensation in favour of the UK due to the ICJ judgement in the Corfu Channel). It was disputable whether the gold belonging formerly to Albania could be redistributed among unsatisfied claimants without the consent of the Albanian State. The Tribunal avoided the problem and decided that it lacked jurisdiction. It refused to render judgment in a situation in which Albania did not participate in the trial; on the other hand, the ICJ has indicated on what terms Albania could join the proceedings. Albania did not meet the conditions, and the Court decided that it was unable to continue the proceeding.

A ruling (decision) in the East Timor case ${ }^{32}$ seems to be even more interesting in the context of the Palestinian-American case. In the proceedings initiated at the request of Portugal, the object would be to assess whether Australia, concluding a maritime delimitation agreement with Indonesia, taking into account the latter's presence in Timor-Leste, annexed in December 1975, violated international law. The UN never acknowledged the annexation, indicating that Timor was never part of the Dutch East Indies, from which Indonesia was formed. The incorporation, on the other hand, was recognised, among others, through Australia and the USA. The ICJ, in the judgment issued on 22.6.1995, stressed that even if the right to self-determination, which the violation of Indonesia invoked in its claim, is effective erga omnes, ${ }^{33}$ this does not automatically mean that every State agrees to submit to the jurisdiction of the Tribunal. Again, the Court would not be able to give a ruling in a situation where it would have to comment on the rights and obligations of a third country not participating in the proceedings. Two judges submitted dissenting opinions. Judge Weeramantry emphasised that the right to self-determination is effective erga omnes, and the obligation to comply with it applies to all States. On the other hand, the ad hoc judge

32 ICJ Rep. 1995, p. 90.

33 The ICJ confirmed its stance recently in the advisory opinion on the Legal Consequences of the Separation of Chagos Archipelago from Mauritius in 1965, 25.2.2019, https://www.icj-cij.org/files/case-related/169/169-20190225-01-00-EN.pdf. 
Skubiszewski pointed out that the Monetary gold rule should not be applied to the Timor case, because, in essence, the ICJ did not have to speak in its ruling on the scope of Indonesia's rights and obligations, but only on the rights and obligations of Australia.

Applying the Timor judgment, and especially the separate opinions in the Palestinian case, it should be stressed that, firstly, the formula adopted in the majority judgment should apply in the case discussed here, since its subject is the rights of the State of Israel, including sovereignty throughout Jerusalem. Therefore, we can discuss the meaning of the right to selfdetermination as the norm of jus cogens, i.e. effective erga omnes, but it certainly is not the norm that defines the place where a diplomatic mission operates. Finally, if we accept that the Court's position is correct (and there is no reason to modify the well-established jurisprudence of the World Court), then the more so the ICJ could not issue a verdict without allowing the State of Israel to participate in the proceeding. It seems that on the basis of the hitherto practice of The Hague Tribunal, it can be assumed with high probability that the Tribunal will escape from the substantive decision, especially since it has a good opportunity to do so.

\section{Bibliography}

1. Arcari M., The relocation of the US embassy to Jerusalem and the obligation of non-recognition in international law, "Questions of International Law" 2018, Zoom-in 50

2. Azarova V., Tell It to the Judge: Palestine's UN Bid and the International Criminal Court, [in:] M. Qafisheh (ed.), 'Palestine Membership in the United Nations: Legal and Practical Implications', Cambridge Scholars Publishing 2013

3. Azarova V., The Trickle-down Effect of Normative Power: the Role of International Courts in Advancing Palestine's Actual Independence, "The Palestine Yearbook of International Law" 2013/14, vol. 17

4. Balmond L., État palestinien, [in:] T. Garcia (ed.), 'La Palestine: d'un Etat non membre de l'Organisation des Nations Unies à un Etat souverain?', Éditions A. Pédone, Paris 2016

5. O'Brien P., Issues related to General Assembly resolution 67/19 on the status of Palestine in the United Nations, http://palestineun.org/wp-content/ uploads/2013/08/012-UN-Memo-regarding-67-19.pdf

6. Christakis Th., L'obligation de non-reconnaissance des situations créées par le recours illicite à la force ou d'autres actes enfreignant des règles fondamentales, [in:] Ch. Tomuschat, J-M. Thouvenin (eds.), 'The Fundamental Rules 
of the International Legal Order', Martinus Nijhoff Publishers, LeidenBoston 2006

7. Crawford J., The Creation of the State of Palestine. Too Much Too Soon, "European Journal of International Law" 1990, vol. 1, no. 1

8. Corten O., Klein P. (eds.), The Vienna Convention on the Law of Treaties. A Commentary, vol. 1, Oxford University Press, Oxford 2011

9. Czapliński W., The Crimean crisis and the Polish practice on non-recognition, "Questions of International Law" 2014, Zoom-out I

10. Dynia E., Uznanie państwa w prawie międzynarodowym, Wyd. Uniwersytetu Rzeszowskiego, Rzeszów 2017

11. Eden P., Palestinian Statehood Trapped between Rhetoric and Realpolitik, "International and Comparative Law Quarterly" 2013, vol. 62, no. 1

12. Forteau M., La Palestine comme État au regard du Statut de la Cour pénale internationale, "Revue belge de droit international" 2012, no. 1

13. Grant Th. D., The Recognition of States : Law and Practice in Debate and Evolution, Westport CT, Praeger, London 1999

14. Høgestøl S., Palestinian Membership of the ICC: A Preliminary Analysis, "Nordic Journal of Human Rights" 2015, vol. 33, no. 3

15. Kattan V., Palestine declares (legal) war on the United States of America, http://victorkattan.com/work/haaretz-publishes -my-take-on-palestine -v-united-states-of-america/

16. Krzan B., Trudne poczq̨tki palestyńskich relacji z Międzynarodowym Trybunałem Karnym [in:] J. Menkes, E. Cała-Wacinkiewicz (eds.), 'Państwo i terytorium w prawie międzynarodowym', C.H. Beck, Warszawa 2015

17. Lagerwall A., The non-recognition of Jerusalem as Israel's capital: A condition for international law to remain relevant?, "Questions of International Law" 2018, Zoom-in 50

18. Milano E, The Doctrine(s) of Non-Recognition: Theoretical Underpinnings and Policy Implications in Dealing with De Facto Regimes, "ESIL Research Forum" 2007, www.esilsedi.eu/fichiers/en/Agora_Milano_060.pdf

19. Momtaz D., La controverse sur le statut de la Palestine, [in:] R. Wolfrum, M. Sersič, T. Šošič (eds.), 'Contemporary Developments in International Law. Essays in honour of Budislav Vukas', Martinus Nijhoff Publishers, Leiden-Boston 2016

20. Palchetti P., La participation de la Palestine à la procédure devant la Cour internationale de justice, [in:] T. Garcia (ed.), 'La Palestine: d'un État non membre de l'Organisation des Nations Unies à un État souverain?', Éditions A. Pédone, Paris 2016

21. Pellet A., The Effects of Palestine's Recognition of the International Criminal Court's Jurisdiction, [in:] Ch. Meloni (ed.), 'Is there a Court for Gaza?', T.M.C. Asser Press, The Hague 2012 
22. Pert A., The 'Duty' on Non-Recognition in Contemporary International Law: Issues and Uncertainties, 'Chinese (Taiwan) Yearbook of International Law \& Affairs' 2012, vol. 30

23. Quigley J., The Statehood of Palestine: International Law in the Middle East, Cambridge University Press, Cambridge 2010

24. Ronen Y., Israel, Palestine and the ICC: Territory Uncharted but not Unknown, "Journal of International Criminal Justice" 2014, vol. 12, no. 1

25. Salmon J., La qualité de l'État palestinien, "Revue belge de droit international" 2012, no. 1

26. Szarek-Zwijacz A., „Państwo Palestyna” - status prawny i aktywność Palestyny we wspótczesnych stosunkach międzynarodowych [in:] J. Menkes, E. CałaWacinkiewicz (eds.), 'Państwo i terytorium w prawie międzynarodowym', C.H. Beck, Warszawa 2015

27. Talmon S., The Duty not to "Recognize as Lawful" a Situation Created by the illegal Use of Force or Other Serious Breaches of a Jus Cogens Obligation: An Obligation Without Real Substance?, [in:] Ch. Tomuschat, J-M. Thouvenin (ed), 'The Fundamental Rules of the International Legal Order', Martinus Nijhoff Publishers, Leiden-Boston 2006

28. Talmon S., The Constitutive versus the Declaratory Theory of Recognition: Tertium Non Datur?, "British Yearbook of International Law" 2005, vol. 75

29. Tse-shyang Chen F., The Meaning of "States" in the Membership Provisions of the United Nations Charter, 'Indian International and Comparative Law Review' 2001, vol. 12, no. 1

30. Vidmar J., Democratic Statehood in International Law. The Emergence of New States in Post-Cold War Practice, Hart Publishing, London et al. 2013

31. Whitman M., Palestine's Statehood and Ability to Litigate in the ICJ, "California Western International Law Journal" 2013, vol. 44, no. 1

32. Wood M., Institutional Aspects of the Guide to Practice on Reservations, "European Journal of International Law" 2013, vol. 24, no. 4

33. Wyler E., Théorie et pratique de la reconnaissance d'État. Une approche épistémologique du droit international, Éditions É. Bruylant, Bruxelles 2013

34. Zimmermann A., Palestine and the International Criminal Court quo vadis? Reach and limits of declarations under Article 12(3), "Journal of International Criminal Justice" 2013, vol. 11, no. 2 